\title{
External cultic tradition and internal ethical purity in Matthew 15
}

\author{
Author: \\ Francois P. Viljoen ${ }^{1}$ \\ Affiliation: \\ ${ }^{1}$ Faculty of Theology, \\ North-West University, \\ Potchefstroom Campus, \\ South Africa \\ Correspondence to: \\ Francois Viljoen \\ Email: \\ viljoen.francois@nwu.ac.za

\section{Postal address:} \\ Private Bag X6001, \\ Potchefstroom 2520, \\ South Africa \\ Dates: \\ Received: 03 Mar. 2014 \\ Accepted: 17 June 2014 \\ Published: 27 Nov. 2014 \\ How to cite this article: \\ Viljoen, F.P., 2014, 'External \\ cultic tradition and internal \\ ethical purity in Matthew \\ 15', In die Skriflig 48(1), Art. \\ \#1818, 12 pages. http:// \\ dx.doi.org/10.4102/ids. \\ v48i1.1818

\section{Copyright:} \\ (C) 2014. The Authors. \\ Licensee: AOSIS \\ OpenJournals. This work \\ is licensed under the \\ Creative Commons \\ Attribution License.
}

Read online:
In Matthew 15:1-20, Jesus responds to the accusation made by the Pharisees and the scribes

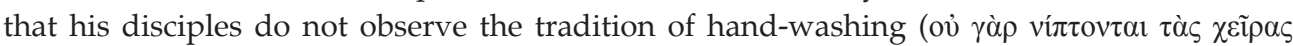

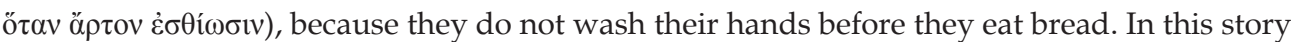
of dispute, two ideas are interwoven, namely the locus of impurity (external or internal)

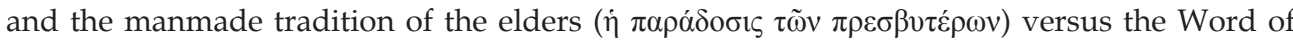
God (ó $\lambda$ ó to ensure purity, whilst Jesus is concerned with inner purity based on God's Word. In this article, the story is interpreted on two levels. The first level describes the dispute between Jesus and the Pharisees. The second level explores the tension the Matthean community experienced in their encounter with Pharisean Judaism of their day - the Judaism of the dual Torah. The question is which aspect of the Torah is challenged by Matthew's Jesus, and what he considers to be the true meaning of the Law. It seems that Matthew uses this story to define and maintain the identity and values of his community over and against that of the Pharisees and their successors. Devices that Matthew uses to define the identity and required morality for his community, are identified. Such devices demonstrate how a community's values can influence the identity and ethics of a society.

In Matteus 15:1-20 reageer Jesus op die aantyging van die Fariseërs en skrifgeleerdes dat sy dissipels nie die handewas-tradisie eerbiedig nie. In hierdie verhaal van dispuut word twee idees vervleg: eerstens dié van die locus van onreinheid, en tweedens dié van mensgemaakte tradisies teenoor die Woord van God. Die Fariseërs word voorgestel as mense wat obsessief is oor mensgemaakte reëls wat reinheid verseker, terwyl Jesus op innerlike reinheid gesteld is, wat op die Woord van God gebaseer is. In hierdie artikel word die verhaal op twee vlakke geïnterpreteer. Die eerste vlak beskryf die dispuut tussen Jesus en die Fariseërs. Die tweede vlak ondersoek die spanning wat die Matteus-gemeenskap in hulle verhouding met die Farisese Judaïsme van hulle tyd ervaar het. Die vraag is watter aspek van die Torah deur die Matteaanse Jesus bevraagteken word, en wat Hy as die ware betekenis van die Wet beskou. Dit wil voorkom asof Matteus hierdie verhaal gebruik om die identiteit en waardes van sy gemeenskap teenoor die dominante Farisese Judaïsme te definieer en te handhaaf. Middele wat Matteus gebruik om die identiteit en verlangde moraliteit van sy gemeenskap te definieer, word geïdentifiseer. Sodanige middele demonstreer hoe 'n gemeenskap se waardes die identiteit en etiek daarvan kan beïnvloed.

\section{Introduction}

Jesus' relation to the Torah forms a central motive in the first Gospel (cf. Loader 1977:165). Perhaps the most important passage in Matthew on the Torah is found in 5:17-19. This article considers this passage as the fundamental statement of Matthew on the Law (cf. Viljoen 2011). In Matthew, Jesus is presented as the ultimate interpreter of this Law (cf. Viljoen 2012). Parallel to this, the Pharisees are described as people obsessed with observing the Torah, both the written and oral traditions. The Gospel continuously describes Jesus and the Pharisees as being in conflict about the true interpretation of the Law. For example, Jesus calls for greater righteousness than the Pharisees and teachers of the Law do (Mt 5:20); ${ }^{1}$ Jesus' halakhic argument on the true intention of the Law (5:21-48); Jesus' response to the accusations of the Pharisees when he ate with tax collectors and sinners $(9: 10-13){ }^{3}$ and the Sabbath controversy $(12: 1-14){ }^{4}$

1.See Viljoen (2013a; 2013b) on the interpretation of righteousness in Matthew.

2.See Viljoen (2013c) on the halakhic argument in the Sermon on the Mount.

3.See Viljoen (2014) on the use of Hosea 6:6 in Matthew 9:13 and 12:7.

4.See Viljoen (2011) on the Sabbath controversy in Matthew. 
In Matthew $15: 1-20^{5}$ the oral Law, as observed and developed by the Pharisees, is in dispute. Different communities of Judaism interpreted the Torah in various ways (Neusner 2007:111). After the destruction of the temple in $70 \mathrm{CE}$, the Pharisees and scribes carried forward the oral traditions, which were associated with the Torah. They formed the community of Judaism that observed the written Torah in accord with these oral traditions. This approach earned them the title and identity of 'the Judaism of the dual Torah' (Neusner 1994:5-7; 2007:111). In the 'Judaism of the dual Torah' the Torah is preserved in three forms: the Hebrew Scriptures, the memorised oral tradition (first written down in the Mishnah ca. 200 CE), and by the sages called rabbi's ${ }^{6}$ (Neusner 1994:5).

The Pharisees believed that God gave Moses, in addition to the written law, also orally transmitted laws. (Cohen 2006:222). ${ }^{7}$ These laws had to be memorised and passed on through generations (Neusner 1971:1-11). The oral laws derived from the written Law, supplement and interpreted it (Cohen 2006:195). The Pharisees believed that the written Torah could not be understood on its own and that it had to be explicated by these oral traditions. Besides the traditions, which they believed had originated from Moses and had been passed on through generations, the Pharisees were very innovative in extending these laws to account for the needs of their own times. Flavius Josephus, the 1st century Romano-Jewish historian, remarks: 'The Pharisees have imposed on the people many laws from the tradition of the fathers not written in the Law of Moses' (Ant. 13. 297). One of these ideas was the development of the laws on hand-washing, which were intended to ensure the observance of purity laws (cf. Mishnah Berkakhot 8:12-14). ${ }^{8}$

In verses 1-20, Jesus responds to the accusation made by the Pharisees and the scribes that his disciples do not observe the tradition of hand-washing. In this story of dispute two ideas are interwoven, namely the locus of impurity (external or internal) and the tradition of the

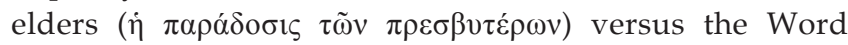
of God (ó $\lambda o ́$ o contrasts the tradition of the elders with the Word of God implies that he does not regard these traditions as coming from God, but as manmade. The Pharisees are depicted as obsessed with external manmade rules to ensure purity,

\section{Further references to Matthew 15 will be indicated only by verses.}

6.A rabbi was considered as equivalent to a scroll of the Torah (Neusner 1994:6) as presented in the following statements from the Babylonian Talmud: 'He who sees a disciple of a sage who has died is as if he sees a scroll of the Torah that has burned' (Y. Moed Qatan 3:7.X), and 'An elder who forgot his learning because of some accident which happened to him - they treat him with the sanctity owed to an ark [of the Torah]' (Y. Moed Qatan 3:1.XI).

7.Rabbinic terminology distinguished between oral and written Torah, as the 'Torah in writing' and the 'Torah by word of mouth' (b. Git. 60b; Midr. Tanhuma, Ki. Tassa 17).

8.The Mishnah Berakhot (completed around the year $200 \mathrm{CE}$ ) states:

1. The House of Shammai say: 'They wash the hands and afterward mix the cup' and the House of Hillel say: 'They mix the cup and afterward wash the hands'.

2. The House of Shammai say: 'He dries his hands on the cloth and lays it on the 2. The House of Shammai say: 'He dries his hands
table' and the House of Hillel say: 'On the pillow'.

3. The House of Shammai say: 'They clean the house, and afterward they wash the hands' and the House of Hillel say: 'They wash the hands, and afterward they clean the house'. whilst Jesus is concerned with inner purity based on God's Word. Earlier in this Gospel the Pharisees' concern about purity is also emphasised when some of them objected to Jesus' association with 'sinners and tax-collectors' (Mt 9:11). The story of hand-washing reflects debates about purity as well as the status of oral Law in comparison to written Law; a debate that emerged during the 1st century CE (Evans 2012:299).

In this article, the story is interpreted on two levels. The first level describes the dispute between Jesus and the Pharisees. The second level explores the tension the Matthean community experienced in their encounter with the Pharisean Judaism ${ }^{9}$ of their time. The Matthean community ${ }^{10}$ was in the process of forming their own identity alongside that of Pharisean Judaism and other main Jewish sects of their time (Overman 1990:41). However, an attempt to reconstruct the social and religious setting of the first audience should be done with caution. Other than in letters, the Gospels do not directly provide such information of their first readers.

The aim of this article is to explain how the dispute as described in verses 1-20 fits into Matthew's overall teaching of Jesus and the Torah. The question is which aspect of the Torah is challenged by Matthew's Jesus, and what he considers to be the true meaning of the Law. It seems that Matthew uses this story to define and maintain the identity of his community over and against the views of the dominant Pharisean Judaism that they encountered. To reach this aim, attention is paid to the three scenes of this story. In the first scene the objection of the Pharisees and the scribes regarding their traditions and Jesus' response is investigated to establish the opposing views on the oral Law. In the second scene, where Jesus addresses the crowds, the central philosophical view of Jesus regarding purity is identified. In the third scene, where Jesus responds to questions of his disciples, Jesus' explanation of his central view on purity is investigated. From this, the investigation devices ${ }^{11}$ that Matthew uses to define the identity and required morality for his community are identified.

\section{The composition of the story}

Verses 1-20 contain a parallel to the hand-washing dispute described in Mark 7:1-23, but with significant changes. For the sake of comparison, significant passages, which only appear in one of the versions, are underlined (see Table 1).

9. While Matthew identifies the Pharisees as chief opponents, a variety of Jewish groups existed throughout the period from the Maccabean revolt to the end of the 1st century. Judaism was quite fragmented and fluid with various groups exercising influence at one stage or another (Cohen 2006:12; Stanton 2013:125; Repschinsk 2000:346). It seems as if the Pharisees were the dominant group in Matthew's situation. See Neusner (1973) on the evolvement of Pharisean Judaism.

10.The 'Matthean community' should not be seen as one small localised group of people who would be able to gather at one house church, but rather as a linked set of communities sharing similar convictions about Jesus (see Stanton 2013:125).

11.In an earlier article the devices ancient authors used to mark the identity of their communities are discussed, for example commitment to a central figure, the naming of groups, claims of ultimate revelation and interpretation, critique the naming of groups, claims of ultimate revelation and interpretation, critique
of opponents, eschatological expectations, and appropriate conduct for their communities (Viljoen 2013b). 
TABLE 1: Comparison between Mark's and Matthew's version of the story.

\section{Mark 7:1-23}

Matthew 15:1-20

\section{Scene 1: Jesus and the Pharisees: Streitgespräch with a challenge and riposte}

\section{Pharisees' challenge}

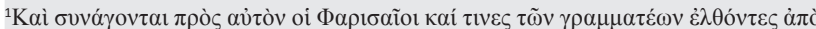

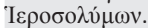

${ }^{1}$ The Pharisees and some of the teachers of the law who had come from Jerusalem gathered around Jesus

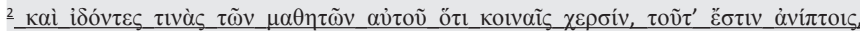

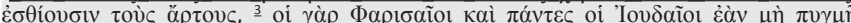

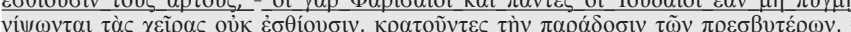

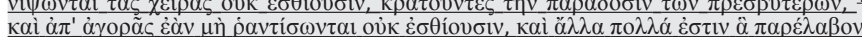

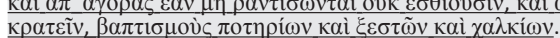

${ }^{2}$ and saw some of his disciples eating food with hands that were defiled, that is, unwashed. ${ }^{3}$ (The Pharisees and all the Jews do not eat unless they give their hands a ceremonial washing, holding to the tradition of the elders. ${ }^{4}$ When they come from the marketplace they do not eat unless they wash. And they observe many other traditions, such as the washing of cups, pitchers and kettles.)

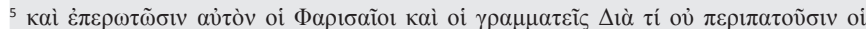

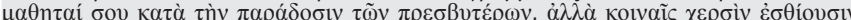

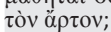

${ }^{5}$ So the Pharisees and teachers of the law asked Jesus, 'Why don't your disciple live according to the tradition of the elders instead of eating their food with defiled hands?'

\section{Jesus' riposte}

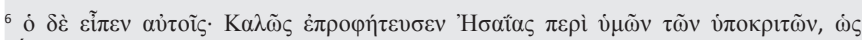
$\gamma \varepsilon \dot{\gamma} \rho \alpha \pi \tau \alpha 1$

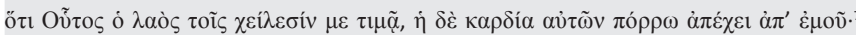

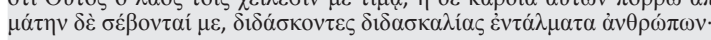

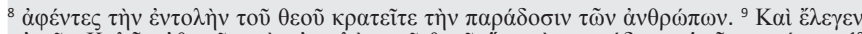

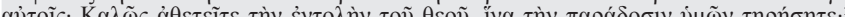

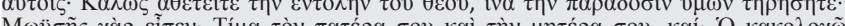

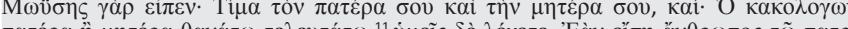

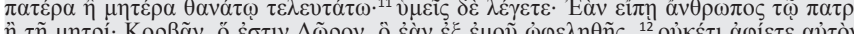

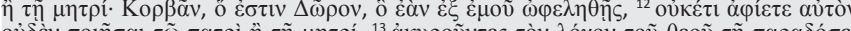

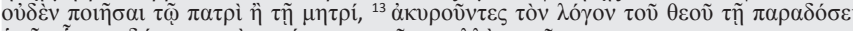

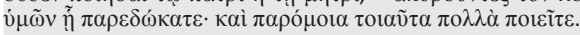

${ }^{6} \mathrm{He}$ replied, 'Isaiah was right when he prophesied about you hypocrites; as it is written:

'"These people honour me with their lips, but their hearts are far from me. ${ }^{7}$ They worship me in vain; their teachings are merely human rules.

"You have let go of the commands of God and are holding on to human traditions."

'And he continued, 'You have a fine way of setting aside the commands of God in order to observec your own traditions! 10 For Moses said, "Honor your father and mother" and, "Anyone who curses their father or mother is to be put to death." "11 But you say that if anyone declares that what might have been used to help their father or mother is Corban (that is, devoted to God) $-^{12}$ then you no longer let them do anything for their father or mother. ${ }^{13}$ Thus you nullify the word of God by your tradition that you have handed down. And you do many things like that.'

\section{Scene 2: Jesus and the crowds: Midpoint axiom}

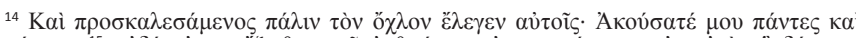

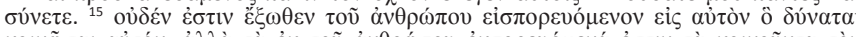

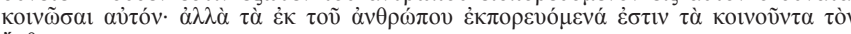
öv $\theta \rho \omega \pi \mathrm{ov}$.

${ }^{14}$ Again Jesus called the crowd to him and said, 'Listen to me, everyone, and understand this. ${ }^{15}$ Nothing outside a person can defile them by going into them. Rather, it is what comes out of a person that defiles them.' $\left.{ }^{16}\right]$

\section{Scene 3: Jesus and his disciples: teaching}

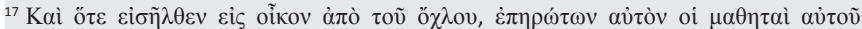

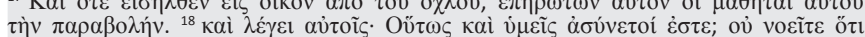

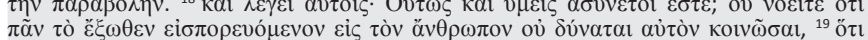

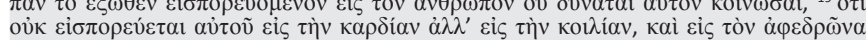

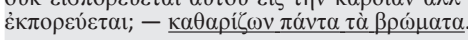

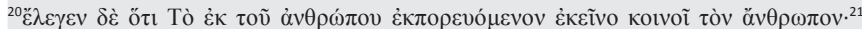

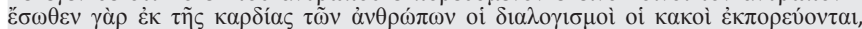

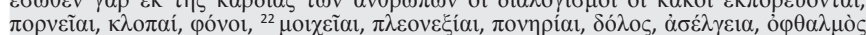

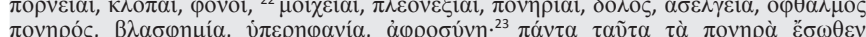

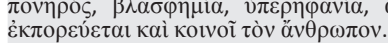

${ }^{17} \mathrm{After}$ he had left the crowd and entered the house, his disciples asked him about this parable. ${ }^{18}$ 'Are you so dull?' he asked 'Don't you see that nothing that enters a person from the Aute stomach, and then out of the body.' (In saying this, Jesus declared all foods clean.)

${ }^{20} \mathrm{He}$ went on: 'What comes out of a person is what defiles them. ${ }^{21}$ For it is from within, out of a person's heart, that evil thoughts come - sexual immorality, theft, murder, ${ }^{22}$ adultery, greed, malice, deceit, lewdness, envy, slander, arrogance and folly. ${ }^{23}$ All these evils come from inside and defile a person.'

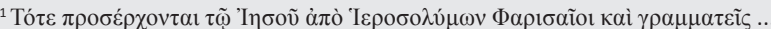

${ }^{1}$ Then some Pharisees and teachers of the law came to Jesus from Jerusalem ...

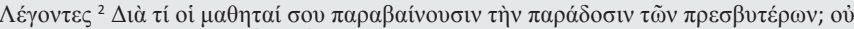

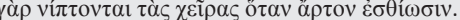

... and asked, ${ }^{2 \prime}$ Why do your disciples break the tradition of the elders, because they don't wash their hands whenever they eat bread!

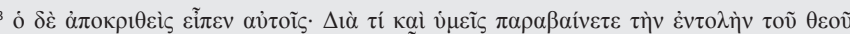

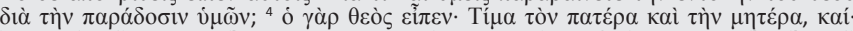

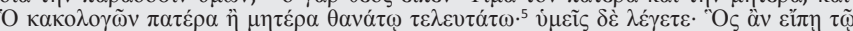

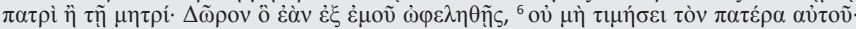

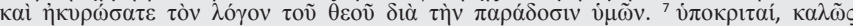

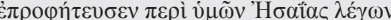

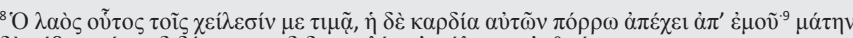

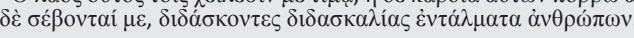

3 Jesus replied, 'And why do you break the command of God for the sake of your tradition? ${ }^{4}$ For God said, "Honour your father and mother" and "Anyone who curses their father or mother is to be put to death." " But you say that if anyone declares that what might have been used to help their father or mother is "devoted to God," "they are not to "honour their father or mother" with it. Thus you nullify the word of God for the sake of your tradition. ${ }^{7}$ You hypocrites! Isaiah was right when he prophesied about you:

${ }^{8 \prime \prime}$ These people honour me with their lips, but their hearts are far from me. ${ }^{9} T$ They worship me in vain; their teachings are merely human rules."

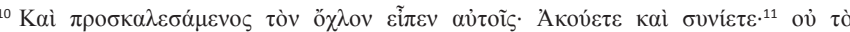

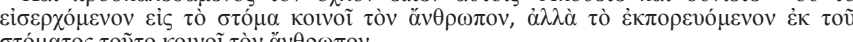

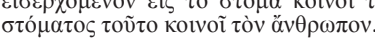

${ }^{10} \mathrm{He}$ called the crowd to him and said, 'Listen and understand. ${ }^{11}$ What goes into someone's mouth does not defile them, but what comes out of their mouth, that is what defiles them.'

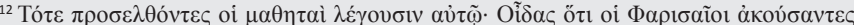

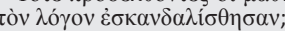

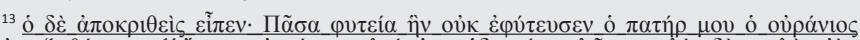

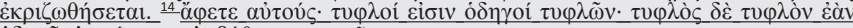

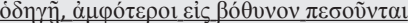

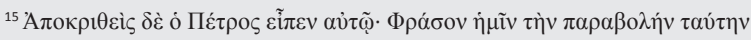

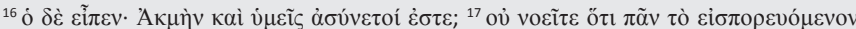

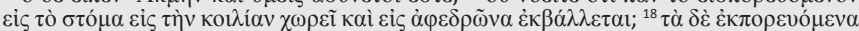

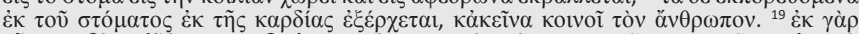

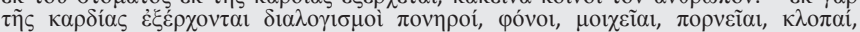

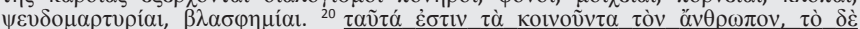

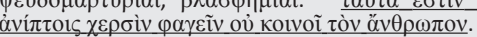

${ }^{12}$ Then the disciples came to him and asked, 'Do you know that the Pharisees were offended when they heard this?'

${ }^{13} \mathrm{He}$ replied, 'Every plant that my heavenly Father has not planted will be pulled up by the roots. ${ }^{14}$ Leave them; they are blind guides. If the blind lead the blind, both will fall into a pit.'

${ }^{15}$ Peter said, 'Explain the parable to us.'

${ }^{16 ‘}$ Are you still so dull?' Jesus asked them. ${ }^{17}$ 'Don't you see that whatever enters the mouth goes into the stomach and then out of the body? ${ }^{18}$ But the things that come out of a person's mouth come from the heart, and these defile them. ${ }^{19}$ For out of the heart come evil thoughts - murder, adultery, sexual immorality, theft, false testimony, slander ${ }^{20}$ These are what defile a person; but eating with unwashed hands does not defile them.' 
Matthew's redaction of the story is quite extensive. He truncates the story by almost half. He omits the section explaining the ceremony of hand-washing (Mk 7:2-4) Matthew commonly omits explanations of Jewish traditions and practices, probably because he, unlike Mark, wrote to a community who were familiar with Jewish traditions. Furthermore, Matthew omits the statement that Jesus made all the food clean (Mk 7:19). He thus limits his discussion to the ritual of hand-washing based on oral tradition without attending to food laws in general. This is quite significant, as it indicates some sensitivity for these Jewish laws with Matthew. On the other hand he adds a parable and a condemnation of the leaders as 'blind guides' (v. 13-14). Such a sharpening of the conflict between Jesus and the Pharisees is typical to Matthew, which signifies a bitter separation between the Pharisean Judaism and the Matthean community. Another addition is the conclusion of Matthew's Jesus with a reference to the washing of hands (v. 20b). He thus refers back to initial challenge to tighten the overall structure of the three scenes of the story, and to emphasise its key issue. Matthew also transposes the quotation of Isaiah 29:13 to the end of Jesus' riposte. ${ }^{12}$ In such a way he tightens the structure of the Streitgespräch. In this story, themes of external tradition and purity are intertwined with the Law and internal purity. Scribal regulations are explicitly set aside (v. 20). Whilst Matthew sharpens the conflict with the Pharisees, he softens Mark's comments on dietary laws. This redaction probably reflects Matthew's and his community's struggle with the Jewish leadership about the value of the Pharisees' tradition, whilst he makes the passage more acceptable for Jewish Christians who probably were inclined to observing dietary laws.

Like in Mark, Matthew 15:1-20 gives an outdrawn objection story in three scenes (Davies \& Allison 2004:516). The story has a close knit structure as can be demonstrated with Figure 1.

The first scene depicts Jesus with the Pharisees and scribes ${ }^{13}$ (v. 1-9); the second scene, Jesus with the crowds (v. 10-11);

12.In Matthew $9: 10-13$ and $12: 1-8$ the Scripture quotation also concludes the controversy stories

13.It is noteworthy that, in the seven times Matthew links the scribes and Pharisees this is the only occurrence where the Pharisees are mentioned first: 'Pharisees and
scribes'. In the other six occurrences the order is 'scribes and Pharisees'. This can be because of Matthew's dependence on Mark here, but more probably Matthew wants to emphasise that the $\pi \alpha \rho \alpha \delta \delta o \sigma ı \zeta$ [traditions] at stake here are specifically those of the Pharisees (Hagner 1995:430). Notably, the reference to the scribes in
this story is been left out later (v. 12).

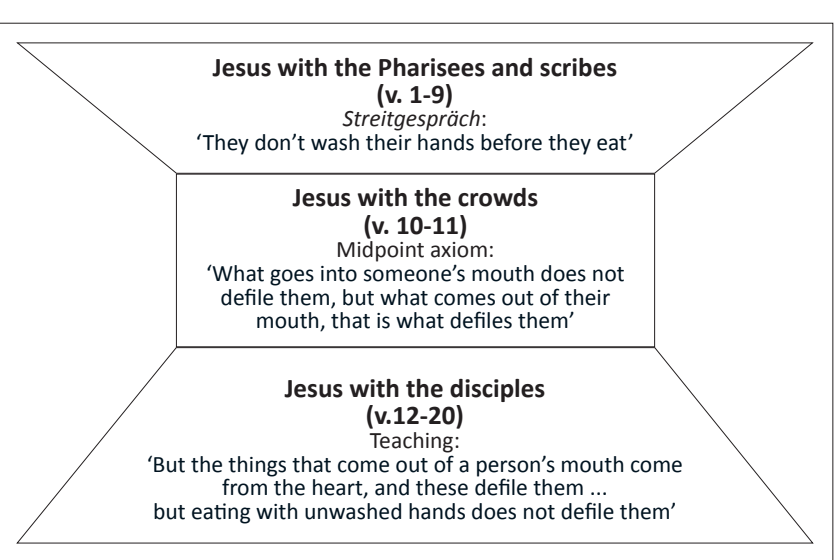

FIGURE 1: Objection story in three scenes. and the third scene, Jesus with the disciples (v. 12-20). ${ }^{14}$ Scenes one and three each begins with a question directed at Jesus: the first scene with a question by the Pharisees and scribes (v. 2-3); and the third scene with a question by the disciples (v. 12). Verse 11 ('What goes into someone's mouth does not defile them, but what comes out of their mouth, that is what defiles them') forms the midpoint of the story (Davies \& Allison 2004:516). It forms a response to the first scene, whilst the third scene provides an explanation of the second scene. Verse 18 elaborates on the response of the midpoint ('But the things that come out of a person's mouth come from the heart, and these defile them'), verse 20 concludes the response ('These are what defile a person; but eating with unwashed hands does not defile them), and refers back to the accusation of verse 2 ('They don't wash their hands before they eat!'). Thus, the third scene creates a sense of unity between the first and second scenes, whilst confirming the main issue in the story.

The significant reference to the 'mouth' in the midpoint of the story should be recognised. In terms of zones of interaction with the world around, the ancient Mediterranean people considered one's mouth to function in the zone of selfexpressive speech (Malina \& Rohrbauch 1992:56). As centre of his argument Matthew's Jesus contrasts the effect of food entering the mouth (which does not defile a person) with self-expressive speech that exits the mouth (which indeed defiles a person).

\section{First scene: Streitgespräch between the Pharisees with the scribes and Jesus (Mt 15:1-9)}

The first scene forms a typical Streitgespräch with the elements of challenge and riposte (Repschinski 2000:254). In honour and shame societies it was a common phenomenon to challenge the honour of an opponent and respond with an equal challenge in return (Malina \& Rohrbauch 1992:42). Such a challenge had to be played in public to reach its aim. The challenge of the Pharisees and scribes (v. 1-2) is countered by Jesus' twofold charge, namely that the Pharisees transgress God's command with their tradition (v. 3-6) and the claim Isaiah prophesied against them (v. 7-9).

\section{Challenge}

The challenge of the Pharisees and scribes consists of a setting, a charge and a reason for the charge, as depicted in Figure 2:

In the setting (v. 1), the hostility of the challenge is highlighted by the reference to the fact that the Pharisees and scribes came from Jerusalem. Jerusalem, not mentioned in the previous ten chapters, ${ }^{15}$ is associated with the home town of

14.In Matthew the Pharisees are usually depicted as disbelieving and hostile; the crowds as potential believers and neutral; and the disciples as believers and loyal.

15.In Matthew, Jerusalem is usually used in a hostile context: Herod and Jerusalem are disturbed when hearing about the new born King (Mt 2:1, 3); Jerusalem is the place where Jesus suffers and get killed $(16: 21 ; 20: 17,18)$; and Jerusalem kills the prophets and stones those sent to them (23:37). Although Jesus had a triumphal entrance into Jerusalem (Mt 21:1), the whole city is stirred and asks: 'Who is this?'(21:10). Matthew, nevertheless, mentions that people from Jerusalem, all Judea and the whole region of the Jordan came to be baptised by John (Mt 3:5), and that large crowds, including of the Jordan came to be baptised by John (Mt 3:5), and that large crowds, including
people from Jerusalem, followed Jesus (4:25). In the Sermon on the Mount, Jerusalem is also mentioned as a place where the Jews swear their oaths (Mt 5:33). 


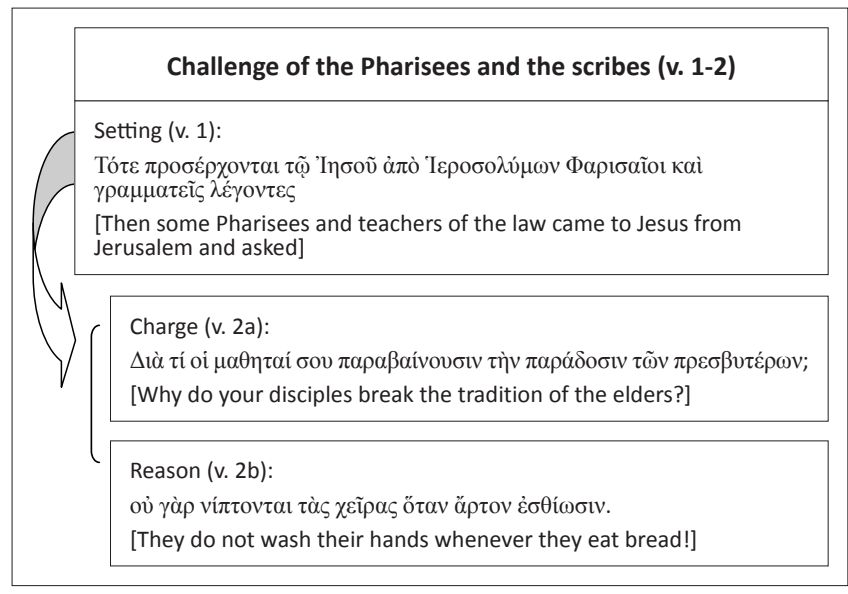

FIGURE 2: Setting, charge and reason for the challenge.

Jesus' opponents (Elliot 1977:462-469). Matthew mentions Pharisees and scribes as a united front opposing Jesus. ${ }^{16}$ The

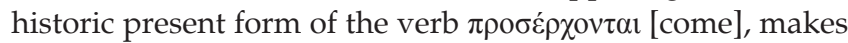
the coming particularly dramatic so that it probably refers to a semi-official delegation sent to test Jesus' faithfulness to the Torah, both written and oral (Osborne 2010:585; Turner 2008:378; Witherington 2006:295). France (2007:575) describes this as 'a foretaste of the confrontation to come'.

In the charge of the Pharisees and the scribes, the status of $\dot{\eta} \pi \alpha \rho \alpha \dot{\delta} \delta \sigma \sigma 1 \varsigma \tau \tilde{\omega} \nu \pi \rho \varepsilon \sigma \beta v \tau \varepsilon \dot{\varepsilon} \rho \omega$ [the tradition of the elders] ${ }^{17}$

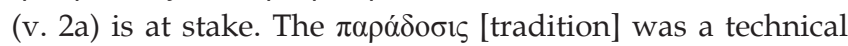
term referring to the collection of Jewish traditions. These traditions went beyond what was written in the Torah (Baumgarten 1987:66). These traditions probably refer to massoret (Davies \& Allison 2004:520). Initially they were transmitted orally and then formalised in the Mishnah around the beginning of 200 CE (Baumgarten 1987:64; Davies \& Allison 2004:520; Neusner 1994:5). In the time of Jesus, the tradition was still quite fluid and the use of such tradition to apply the Torah was regarded as quite innovative ${ }^{18}$ (Senior 1998:176). Schiffman (1994:280-281) remarks that during the late Second Temple Judaism 'sectarian law was a living, developing phenomenon constantly giving rise to new compilations of lists of laws'. After the destruction of the temple, the Pharisees and scribes felt themselves obliged to preserve these oral traditions (Neusner 2007:111).

The reason for the charge refers to the transgressing ( $\pi \alpha \rho \alpha \beta \alpha^{\prime} v_{0} v \sigma v^{19}$; [they transgress]) of the tradition of handwashing (v. 2b). The tradition of hand-washing was more than a hygienic custom. It formed part of ceremonial and ritual cleansing. There is no commandment in the Hebrew

16. In Mark 7:1 the Pharisees seem to be already in place, while certain scribes came from Jerusalem.

17.In the Gospels, only Mark and Matthew use this word, and only in the context of this story.

18.Some rabbinic traditions indicate that the tradition was valued more than the written Torah: 'Greater stringency applies to the observance of the words of the scribes than to the observance of the works of the written Law' (m. Sanh. 11:3); and 'My son, be more careful in the observance of the words of the scribes than and 'My son, be more careful in the observance of the words of the scribes than
in the words of the Torah ... whoever transgresses any of the enactments of the Scribes incurs the penalty of death' (b. Eruv. 21b; Talbert 2010:188).

19.The verb $\pi \alpha \rho \alpha \beta \alpha i v \omega$ [transgress] is only used three times: twice in this context (v. 2, 3) and once to describe the act of Judas 'to go where he belongs' (Ac 1:25).
Bible concerning the washing of hands for ordinary meals. It seems that the Pharisees adopted the requirement set for priests before they ate consecrated food. The Pharisees also applied these requirements to themselves and all Jews, even when eating ordinary food ${ }^{20}$ (Booth 1986:173; Carter 2000:316; Finklestein 1966:278; Hagner 1995:430; Neusner 1973:83; Witherington 2006:296). This tradition goes back as far as regulations imposed by the rabbi schools of Hillel and Shammai early in the 1st century CE (Hauck 1964:946-948). Neusner attests that the practice of hand-washing prevailed amongst Pharisees in the time of Jesus. He writes: 'What was the dominant trait of Pharisees before 70 C.E.? It was ... concern for the matters of rite, in particular, eating one's meals in a state of ritual purity as if one were a temple priest' (Neusner 1977:670). The tradition of hand-washing thus developed as an identity marker of the Pharisees. The Pharisees reasoned that there were many unclean objects that one would touch during a day. This would lead to unclean hands and when touching food with unclean hands would result in unclean food. When eating such unclean food, one would become unclean. The tradition therefore evolved that all Jews had to perform a ritual of handwashing along with the blessing that preceded the eating of meals (Mishnah. Ber. 8:2-4). The Yadayim ${ }^{21}$ is a treatise of the Mishnah (ca. 200 CE) and the Tosefta (ca. 300 CE), dealing with the laws of hand-washing and their ritual impurity. The issue of hand-washing became so important that a whole tractate in the Babylonian Talmud (ca. $600 \mathrm{CE}$ ), the Yadayim [the Hands], was devoted to this. Although it is clear that the Pharisees observed traditions of hand-washing in the time of Jesus and when Matthew wrote his gospel, it is difficult to determine to what extent this developed legislation of Yadayim, as described in Rabbinic literature, was observed in the times of Jesus.

In verse 2 ö $\tau \alpha v$ [whenever] is inserted to describe the practice of Jesus' disciples. Eating with unwashed hands was not a single incident, but a customary procedure. This probably reflects a custom of the Matthean community, which was in conflict with the traditions of the elders (Repschinski 2000:156). This issue about the washing of hands before meals might be an example of the Matthean community breaking with Pharisaic traditions.

\section{Riposte}

In Matthew's story, Jesus responds to the accusation of the Pharisees and Sadducees in a twofold manner. First he

20.Mark 7:3 explains this habit: 'The Pharisees and all the Jews do not eat unless they give their hands a ceremonial washing, holding to the tradition of the elders.' John 2:6 also implies such a custom: 'Nearby stood six stone water jars, the kind used by the Jews for ceremonial washing.' It seems that this habit was widespread.

21.The treatise on the Yadayim is 11th in the order of Tohorot in most editions of the Mishnah, and is divided into four chapters, containing 22 paragraphs in all (Herr 2007:264). The first chapter deals with the quantity of water that is needed to wash hands when pouring it over them; the vessels from which the water may be poured over the hands; the kinds of water, which may not be used to cleanse the hands; and persons who may perform the act of manual ablution. The second chapte and persons who may perform the act of manual ablution. The second chapter deals with how the water should be poured over the hands; the first and second washing and doubtful cases, which include whether the ablution was properly performed. Chapters 3 and 4 discuss the objects which make hands unclean with specific reference to the canonical books. According to this tractate everyone therefore had to eat everyday meals in a state of ritual purity as if one where a temple priest (Davies \& Allison 2004:521). The Qumran-community required tota immersion before a meal (1 QS3.8-9; 5:13; CD 10:10-13; Newton 1985:26). 
charges them with the fact that their tradition causes them to violate God's commandments (v.3-6) and secondly that Isaiah prophesied against their way of worship (v. 7-9).

Other than in Mark 7:8-9, Matthew does not open Jesus' riposte with reference to Isaiah 29:13, but with a counter argument that parallels the question posed by the Pharisees and the scribes (Repschinski 2000:159). As the Pharisees accused the disciples with the words, 'Why do your disciples break ( $\pi \alpha \rho \alpha \beta \alpha$ ivovovv) the tradition of the elders?' (v. 2), Jesus begins his response with 'And why do you

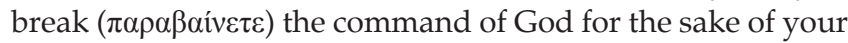
tradition?' (v. 3), using the same verb.

In the first part of the counter charge, the tradition ( $\pi \alpha \rho \alpha \dot{\delta} \delta \sigma 1 \varsigma)$ of the Pharisees is contrasted in parallel form with the command of God ( $\dot{\varepsilon} v \tau \mathrm{\nu} \lambda \grave{\eta})^{22}$ and the Word of God

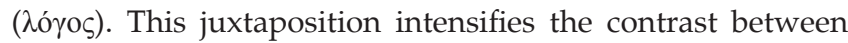
God's commandments and manmade legislation:

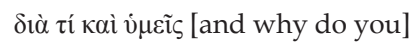

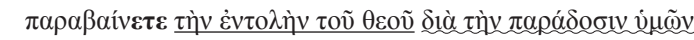
[break the command of God for the sake (because) of your tradition?] (v. 3)

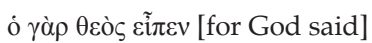

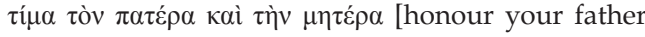
and mother]

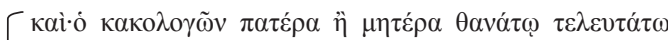
[and anyone who curses their father or mother is to be put to death] (v. 4)

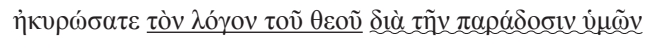
[thus you nullify the word of God for the sake of your tradition] (v. 6b)

Verses 3 and 6 have parallel phrases:

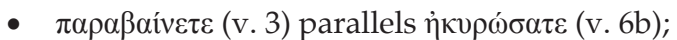

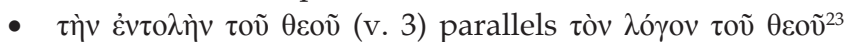
(v. 6b); and

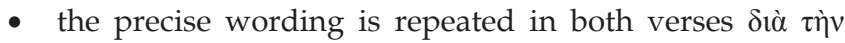
$\pi \alpha \rho \alpha ́ \delta$ oøı $v \mu \tilde{\omega} v$ [for the sake (because ${ }^{24}$ ) of your tradition] (v. 3 and $6 b)$.

These parallel phrases make the same point. Jesus charges the Pharisees with the accusation that they break and nullify the command and Word of God, not 'despite your [their] tradition', but much harsher, 'for the sake (because) of your [their] tradition'. Whilst Mark 7:8 speaks of the tradition of people ( that it is 'your' tradition ( $\left.\pi \alpha \rho \alpha \dot{\delta} \delta \sigma \_v \dot{v} \mu \tilde{\omega} v\right)$. Implicitly the juxtaposition is not only between the Law and the tradition, but (more personal) also between God, the Pharisees and the

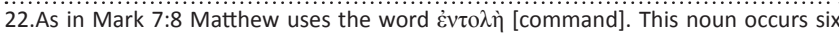
times in Matthew $(5: 19 ; 15: 3 ; 19: 17 ; 22: 36,38,40)$ referring to the commandments of the Law. Matthew uses vómoc to refer to the Law, which consists of different commandments (Mt 5:17, 18; 7:12; 11:13; 12:5; 22:36, 40).

23.Within this context 'of God' ( $\tau$ oṽ $\theta \varepsilon o v ̃$ ) in verses 3 and $6 \mathrm{~b}$ is a subjective genitive referring to what God commanded and said.

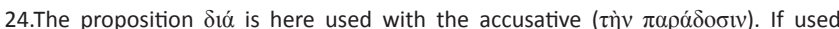
with the accusative, the meaning can be defined as 'through, on account of, by reason of, for the sake of, because of'. If used with the genitive, the meaning can be 'through, throughout, by the instrumentality of' (Blass \& Debrunner 1961:119). scribes. Matthew's Jesus thus argues that his disciples do not follow the tradition of the Pharisees, because the Pharisees do not follow the commandment of God (Repschinski 2000:159). Matthew's Jesus is clearly opposed to 'Dual Torah', an identity marker of the Pharisean Judaism, as portrayed here. This signifies a separation of the Matthean community of the observance of rabbinic traditions.

The parallel phrases form an inclusio of verses $4 \mathrm{~b}-6 \mathrm{a}$ in which Jesus gives an example of how the tradition is used to break the command of God. The command of God is referred to as something that God said: ò $\gamma \grave{\alpha} \rho \theta \varepsilon o ̀ \varsigma ~ \varepsilon \tilde{i} \pi \varepsilon v$ [for God said] (v. 4a, 6b). The divine origin of the commandment is emphasised and contrasted with the manmade tradition. What God said cannot be compared to the tradition of people. Manmade commandments cannot substitute divine commandments. Morris (1992:394) comments about this Pharisean tradition: 'Their motives may possibly have been excellent, but the result was deplorable.'

This counter challenge probably reveals the rivalry between the Matthean community and Pharisean Judaism of their day about being the real keepers of God's Law. In their desire to meet the specific obligations of the Law, they engaged in competitive disputes as to what they meant. Each group claimed to be living according to the principles of the Torah, but then implied that others were not doing so (Dunn 2003:292).

In verse 5 Jesus elaborates on his previous statement and continues to contrast the commandment of God with the behaviour of the Pharisees. He refers to the fifth commandment ('Honour your father and your mother'; Ex 29:12) and a regulation ('Let the one be put to death who speaks evil of their father and mother'; Ex 21:17), which enforces the seriousness of breaking the fifth commandment. Tí $\mu$ [honour] is an emphatic present meaning that one has to honour one's parents at all times, which includes caring for them financially (Derret 1977:112-117). From the Gospel accounts it seems as if the Pharisees introduced the tradition that children could dedicate the money, with which they were supposed to support their parents, as a gift to God. The Mishnah Ned. 9.1 refers to such Corban vows and the honour one owes to father and mother. ${ }^{25}$ Whilst performing this cultic activity, they neglect their moral duty to care for their parents. Bailey (2000:193-209) explains the Jewish backgrounds to this misuse of the Corban and how this led to a growing antagonism against the Pharisees.

Jesus, however, regards the written Law of Moses as the commandment of God. Several phrases are therefore used to refer to these stipulations of the Torah: the command of God

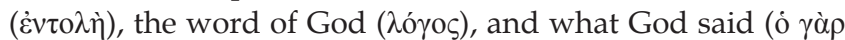

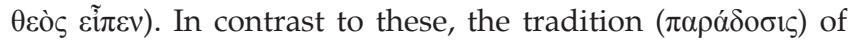
the Pharisees is considered as an infringement. As a result of their tradition, they legally invalidate the Word of God

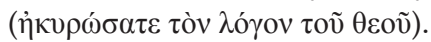

25.Though Corban vows were performed in the time of Jesus and when Matthew wrote his gospel, it is difficult to determine to what extent it was done at that stage. 


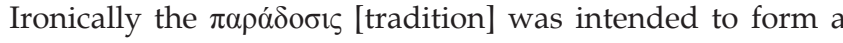
fence around the written Torah (Hagner 1995:430; Osborne 2010:585), but Jesus accuses the Pharisees of the fact that this

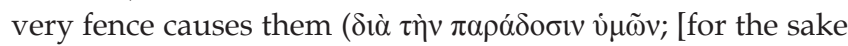
of your tradition]) to break God's commandments. There was much dispute in ancient times about the status of this tradition, even beyond the New Testament. There was a variety of viewpoints amongst the Pharisees, Saducees and the Qumran community on purity issues (Bowley 2000:873). The more conservative Sadducees opposed these traditions, arguing that:

the Pharisees had passed down to the people certain regulations handed down by former generations and not recorded in the law of $\operatorname{Moses}^{26}[$ and $]$ for [this] reason they are rejected by the Sadducean group (Josephus, Ant. 13.10.6). ${ }^{27}$

According to some of the Sadducees, the $\pi \alpha \rho \alpha$ ódoois led to unnecessary self-denial (Ps. Clem. Recog. 1. 53-54). As the Sadducees did not believe in an afterlife, they regarded this burden and loss of pleasure as useless and a Pharisaic pursuit of an illusion (Baumgarten 1987:70). The composers of the Dead Sea Scrolls also criticised these traditions 'Teachers of lies ... have schemed a devilish scheme ... to exchange the law engraved on my heart by Thee for the smooth things (which they speak ${ }^{28} ; 1 \mathrm{QH}$ 4.14-15). The Pharisees were sensitive to such criticism, as they often referred to the 'tradition of the fathers' ${ }^{29}$ or the 'tradition of the elders' 30 (Josephus, Ant. 10.51 and 13.408). They attempted to give their traditions a reliable pedigree, as the fathers and elders were regarded as the leaders of the nation. As family traditions were widely respected in antiquity, the Pharisees indicated that the tradition of the fathers and elders was more than just that of a school..$^{31}$ It therefore seems that the critique on the tradition in verses $1-20$, at least in part, reflects conventional criticism $^{32}$ against the Pharisean tradition (Carter 2000:315).

Jesus enforces his criticism of the tradition with a second charge (v. 7-9). He addresses the Pharisees with the negative

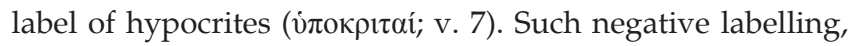
referring to stereotypes was common practice in a challenge and riposte setting (Malina \& Rohrbauch 1992:98). People were not known for their individual personalities, but by social categories and groups they belonged to. Stereotypes could be either positive or negative. When Matthew's Jesus

26.Baumgarten (1987:70-71) points out that modern scholarship increasingly observes that the laws in the Mishnah often bears little relation to the written Torah.

27.When they were in power under Hyrcanus, the Sadducees even punished the Jews who followed the $\pi \alpha \rho \alpha$ ó $\delta$ orc of the Pharisees (Josephus, Ant. 13.10.6), but when the Pharisees came back into power under Alexandra, they reinstated the tradition (Josephus, Ant. 13.6.2; see Baumgarten 1987:69).

28.In the Dead Sea Scrolls the speakers of smooth things are identified as the Pharisees (Davies \& Allison 2004:520.)

29.In Galatians 1:14 Paul also refers to the extreme zeal for 'the tradition of the fathers', which he earlier had.

30.Matthew 15:3 and Mark 7:3 use the term tradition of the elders.

31.By making their tradition priestly, they took it further than what is plausible, as there was also competition between the Pharisees and the priests (Baumgarten 1987:73).

32.As could be expected, the Church Fathers followed the Gospels in criticising the traditions of the Pharisees (e.g. Just, Dial. 38; Clem. Al. Strom. 6.7.58.2; Iren. Adv. Haer. 4.12.1; Klijn \& Reinink 1973:220-223). uses the negative stereotype of 'hypocrites' to label the Pharisees, he seriously challenges their credibility in the community. Jesus states that they pretend to be different from who they really are. They pretend to worship God, but they fail in this regard. Jesus claims that Isaiah actually prophesied about their attitude, as the prophet of old raised a similar complaint against the religious authorities of his (Isaiah's) day. The addressees of Matthew 15 would all agree that the people Isaiah denounces were hypocrites. Based on what he previously argued (v. 3-6) about the Pharisees, Matthew's Jesus now states that the Pharisees are just like the people in Isaiah's days - hypocrites too. Jesus refers to Isaiah 29:13 providing two reasons as to why the Pharisees should be considered as hypocrites:

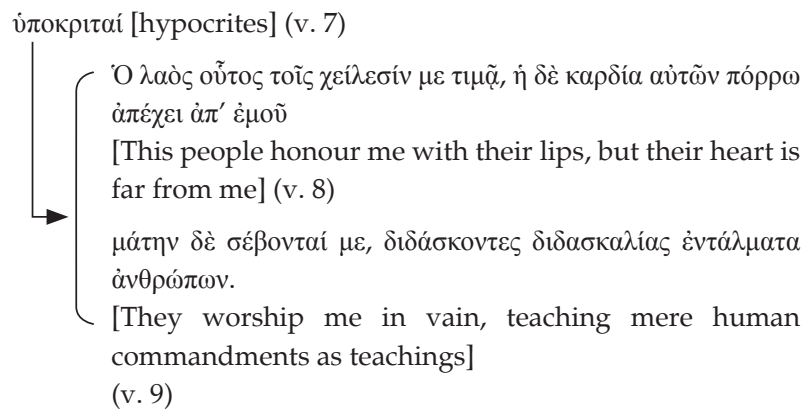

The first reason is that they pretend to worship God, but they do so with their lips and not with their hearts (v. 8). Osborne (2010:587) interprets this statement: 'a detailed Torah tradition without heart commitment is irrelevant before God'. According to the traditional Mediterranean thought, this implies that they were behaving with the zone of speech, but without the zone of emotion-fused thought. Mediterranean people thought of a person in terms of zones of interaction with the world around, namely the zones of emotion-fused thought which involves the activity of the eyes and heart (sight, insight, loving, valuing, etc.), the zone of self-expressive speech, which involves the activity of the mouth ${ }^{33}$ and ears (speaking, hearing, etc.) and the zone of purposeful action, which involves the hands, fingers and legs (touching, walking, accomplishing, etc.; Malina \& Rohrbauch 1992:56). Human activity could be described in terms of a particular zone of activity or a combination of these zones. Jesus charges the Pharisees that only one zone of activity is involved when they honour God, whilst the heart is not involved. One's heart was considered as one's religious centre which forms the root of religious life and ethical conduct (Walker 2000:563). It refers to the affective centre or desire producer of one's being and the seat of thought and understanding (Behm 1978:611-613). The Pharisees' hearts were lacking in their honour to God.

The second reason why Jesus regards their honour of God superficial is that they adhere to precepts of human origin and not of the Law God has given. They worship God by teaching mere human commandments as teachings (v. 9). In

33.The Isaiah quotation refers to 'lips' and Jesus' argument in verse 8 is that the 'lipzone' when speaking, is detached from the 'heart-zone' of their personalities. Significantly in verses 10 and 18 , Jesus indeed links what exits the 'mouth' with the heart, but not food that enters through the mouth, as it goes to the stomach and then exits the body ( $v .10)$. 
this prophecy, Isaiah warns his people against the vanity of their worship if it is based on the teachings of people. They try to do this with their own manmade tradition by which they replace the commandments of God. The alliteration of $\delta 1 \delta \alpha ́ \sigma \kappa o v \tau \varepsilon \varsigma \delta 1 \delta \alpha \sigma \kappa \alpha \lambda i \alpha \varsigma$ emphasises the importance of 'teaching teachings'. Matthew's Jesus defines the 'tradition of the elders' ( $\dot{\eta} \pi \alpha \alpha \dot{\delta} \delta 0 \sigma 1 \varsigma \tau \tilde{\omega} v \pi \rho \varepsilon \sigma \beta v \tau \varepsilon \dot{\varepsilon} \rho \omega v ;$ v. 2, 3) as human 'teaching of teachings'. Teaching must be based on God's truth, not on human ideas. Matthew's Jesus clearly rejects this oral tradition.

The Pharisees and scribes do not respond to Jesus. The Streitgespräch ends with Jesus victoriously having the final say.

From the first scene the following conclusions can be drawn regarding the Law: this scene clearly pronounces the Pharisees' concern for purity and the observance of their tradition. According to them, the ritual of hand-washing was necessary to ensure purity. Jesus opposes their view by contrasting manmade traditions with the Word and commandments of God. With biting irony he charges them with the fact that their tradition causes people to nullify God's Law. They are hypocrites, as they pretend to be honoring God by observing their tradition, but by doing this they are actually doing the opposite.

This Streitgespräch reveals the rivalry between Judaism of the 'Dual Torah' and the Matthean community. The Pharisees in the story represent the Judaists who valued the oral Law as important as the written Law. The story describes the oral Law as manmade traditions in contrast to the written Law as the Word of God. Based on the performance of Jesus, he and thus Matthew and his community, distance themselves from these oral traditions and regard themselves as faithful to the real Torah.

\section{Second scene: Axiom of Jesus before the crowds (Mt 15:10-11)}

The next scene of the story is introduced with Jesus turning to the crowds (v. 10). Having rebuked the Pharisees, he continues by stating an axiom to the crowd. For Matthew's Jesus, the Pharisees with the scribes and the Jewish crowds are different kind of groups who are treated differently. Pharisees and scribes are usually depicted as hostile and disbelieving (cf. Mt 9:34; 12:2, 14), whilst the crowds are considered as neutral. They are potential believers, but can also be easily convinced by the Jewish leaders to reject Jesus. $^{34}$

In this second scene Jesus addresses the crowds on the issue of defilement (v. 10-11). The crowd being potential believers,

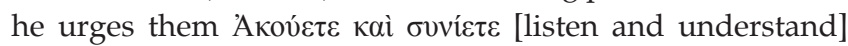
(v. 10). If they only listen, they will remain the crowd, but

34.At several occasions Matthew mentions that Jesus saw and addressed the crowd (Mt $5: 1 ; 13: 2,34)$, that he felt compassion towards them $(9: 36 ; 14: 14,19)$, how the crowds followed Jesus $(4: 25 ; 8: 1 ; 14: 13)$, and that they were deeply impressed and amazed by his teaching $(7: 28 ; 9: 33)$. However, the crowd was also persuaded by amazed by his teaching $(7: 28 ; 9: 33)$. However, the crowd was also persu
the chief priests and the elders to ask Jesus to be crucified (Mt 27:20). if they understand, they will become disciples. In Matthew 'understanding' is the distinctive response of disciples (Mt 13:13-15, 19, 23, 51; cf. France 2007:582). What Jesus then tells them in a contrasting parallel axiomatic statement (v. 11), forms the midpoint of the story. He postulates this principle as the basis for further arguments against the viewpoint of the Pharisees:

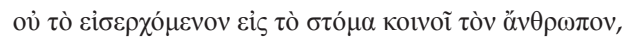

[What goes into someone's mouth does not defile him]

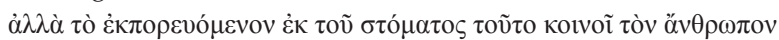

[but what comes out of his mouth, that is what defiles him].

On the one hand the contrast lies between what is entering

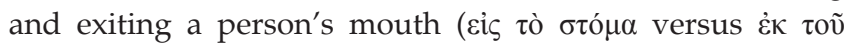
$\sigma \tau$ ó $\mu \alpha \tau(\varsigma)$, and on the other hand, between material and spiritual references. ${ }^{35}$ Matthew omits Mark's statement that Jesus made all food clean (Mk 7:19). It seems as if Matthew intentionally refrains from making a statement about the overthrowing of food laws as such (e.g. Booth 1986:221; Davies \& Allison 2004:527; Hagner 1995:437; Luz 2001:332). Matthew, with his mainly Jewish-Christian audience, might have been more hesitant to explicitly include Mark's comment. Osborne (2010:588) and Witherington (2006:296) conversely argue that Mark's comment is surely implied in Matthew's text. According to them, Matthew merely shortened the text as he often does. Whatever the case, the dispute in the story is not about food laws as such, but about the oral traditions of the Pharisees versus the written Torah. The oral tradition of hand-washing was intended to prevent impurity to enter the body, and Matthew's Jesus distances himself from this tradition.

However, a second dimension about Jesus' understanding of the Law is added in his statement, namely that what people eat, even if their food is contaminated with unwashed hands, cannot defile (кovvoĩ) ${ }^{36}$ them. To the contrary, defilement is caused by the moral intention of a person. Jesus argues that true defilement does not come about as a result of consuming possibly contaminated food, as defilement is a moral issue (Carlston 1968-69:75). ${ }^{37}$ Words coming from the mouth, results from the self-expressive zone of a person and is selfrevealing (Malina \& Rohrbauch 1992:56). Words reveal the inner morality of a person, and thus show that the whole person is unclean. This relates to a remark Jesus made earlier in the text: 'For the mouth speaks what the heart is full of' (Mt 12:34). Morris (1992:395) makes a fitting comment: 'Words that go out of the mouth are more likely to indicate defilement than food that goes in.' Verse 11 can somehow be regarded as a crux interpretum for the understanding of the

35 . Using tradition historical and legal historical arguments Booth $(1986: 214)$ suggests the logion of the historical Jesus to be: 'There is nothing outside a man which cultically defiles him as much as the things coming from a man ethically defile him. According to Booth, it is credible that Jesus would depreciate external cultic purity in favour of internal ethical purity.

36.The use of the verb ' $\kappa o v v o \tilde{\prime}$ ', is significant. The word usually means 'make common' or 'share', but the meaning is transferred to 'defile'. The explanation of this seems to 'se in the distinction between 'holy' and 'general' in ritual terms. What is holy to lie in the distinction between "holy' and 'general' in ritual terms. What is holy is suitable for ritual use and should be distinguished from what is only useful for general use. To 'defile' something, is to make it ceremonially unclean (Davies \&
Allison 2004:527; Morris 1992:395).

37.In Matthew 23:23-26 Jesus emphasises the importance of internal rather than external purity. 
law, because Matthews' Jesus uses irony to expose untrue human piety and external purity by comparing it with true piety and internal purity. ${ }^{38}$

According to rabbinic writings, there was also an opinion amongst rabbis that God would once again permit the eating of all flesh in the Messianic age (Midr, Teh. on Ps 146:7). Based on passages like Numbers 14:21: 'all the earth shall be filled with the glory of the Lord', and Zechariah 14:21: 'Every pot in Jerusalem and Judah will be holy to the Lord Almighty, and all who come to sacrifice will take some of the pots and cook in them', they assumed that complete purity and total sanctification will once again exist according to these biblical references (Davies \& Allison 2004:527; Talbert 2010:188). However, as Matthew omits Mark's reference that Jesus declared all foods clean (Mk 7:19b), he limits the issue to the tradition of hand-washing. Matthew's Jesus explicitly rejects the ritual of hand-washing without making any particular remark on food laws. In the Matthean community's conflict with the Pharisean Judaism the status of the oral traditions apparently was a main issue. Food laws as such, did not form part of the debate.

\section{Third scene: Jesus teaching his disciples (Mt 15:12-20)}

In the third scene, Jesus turns to his disciples, his own group. Jesus responds to their question about him having upset the Pharisees: ${ }^{39}$ 'Do you know that the Pharisees were offended when they heard this?' (v. 12). ${ }^{40}$ Jesus responds to the group of people who are regarded as believers and people who are supposed to understand. Jesus provides two explanations (v. 13-14, 16-19) and a conclusion (v. 20), which ties the story together. In this performative speech, ${ }^{41}$ Jesus not only passively describes the position of the Pharisees and purity, but changes the way his disciples perceive their religious and social reality.

The first explanation (v. 13-14) does not occur in Mark. This addition is noteworthy as Matthew usually shortens Mark's version. Once Matthew adds to Mark's version, it signifies an issue the evangelist wants to emphasise. Matthew's Jesus uses two metaphors: about plants planted by God and about blind guides. These two metaphors are separated by an exhortation to leave the Pharisees

38.Similar sentiments about defilement, namely in a moral rather than physical sense, are found in extra-biblical literature. Manader (frag. 540) writes: 'All that brings defilement comes from within'; Philo (Spec. Leg. 3:209) remarks: 'For the unjust and impious man is in the truest sense unclean'; and Sextus (Sent. 110): 'a person is not defiled by the food and drink he consumes, but by those acts which result form an evil character' (cf. Davies \& Allison 2004:526-527). Jesus was therefore not form an evil character' (cf. Davies \& Allison 2004:
the only one in this time to utter such critique.

39.The scribes, as referred to in verse 1, are not mentioned here. Matthew's remark that the disciples were concerned about offending the Pharisees is unique to Matthew and somewhat odd, as the Pharisees are usually portrayed as the opponents of Jesus and his disciples. In Mark the disciples merely ask for an explanation. This is the only occurrence of such concern for Pharisees in the Matthean Gospel.

40.The Pharisees' honour was impaired and the disciples, living in an honour and shame society, realised this (cf. Malina \& Rohrbauch 1992:42).

41.Performative utterances are defined in the Speech acts theory which refers to statements that change the (social) reality they are describing. The contemporary use of the term goes back to Austin's definition of performative language (Austin 2005).

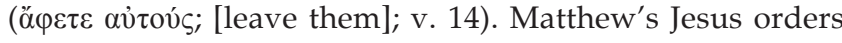
his disciples, and thus Matthew and his community, to part from the Pharisees and their teaching. Jesus tells his disciples that the Pharisees are like plants not planted by his 'heavenly Father' that will be weeded in judgement (v. 13). ${ }^{42}$ When Jesus refers to God as 'my Father', he not only indicates his special relation with God, but also his authority to critique the Pharisees (Witherington 2006:298). Furthermore, Jesus denotes the Pharisees as blind guides misleading other blind people (v. 14). With irony and wordplay Jesus remarks that the Pharisees regard themselves as guides for the blind, ${ }^{43}$ but they are actually blind themselves. There is no use in arguing with them, as they are not able to see and discern the truth, that is, they are not able to understand. Jesus argues that whilst the Pharisees regard themselves as teachers of the Law, they are blind for God's true law (Osborne 2010:590). Even worse, they increase the blindness of the people they guide. The ancient Mediterranean people believed that one could see, because light proceeded from their hearts through their eyes (Malina \& Rohrbauch 1992:64; Viljoen 2009). On the other hand, with blind people darkness proceeded from their hearts through their eyes, indicating that there was something wrong in their hearts. Darkness was not considered as the absence of light, but as an objective evil reality. This criticism anticipates the diatribe of Matthew 23:16 and 24 where the scribes and Pharisees are also denoted as 'blind guides' (Evans 2012:301).

This interpolated explanation probably reflects the tension between the Matthean community and the Pharisaic Judaism of their time. The remark that the disciples should leave the Pharisees, could refer to the separation between church and synagogue (Gundry 1994:307). The issue at stake is not limited to the tradition of hand-washing, but it is about the status of the Pharisees and their teachings in general. The community is warned not to be misled by the Pharisees and rather to go their own way.

In his second explanation (v. 16-19), Jesus responds to the request of Peter to explain the parable ( $\left.\tau \grave{\eta} v \pi \alpha \rho \alpha \beta \rho \lambda \eta v^{44}\right)$ to them (v. 15). Jesus' response includes all the material from v. 11-14, but the argument about what goes into the mouth and what exits it, is mainly intended. Jesus responds with two questions: 'Are you also still without understanding?' (v. 16) and 'Don't you see that whatever enters the mouth goes into the stomach and then out of the body?' (Mt 5:17).

42.The comparison of the plants reminds the reader of the parable of the wheat and the weeds (Mt 13:24-30). In verse 16 Jesus warns that the Pharisees and the scribes run the risk of being identified as bad seeds, as plants not planted by God and be rooted up on judgement day (Evans 2012:301). Evidently Isaiah 60:21 ('Your people shall all be righteous ... the shoot that I planted, the work of my hands') resonates in these comparisons. Jesus' warning stands in contrast to rabbinic interpretation of Isaiah 60 that finds in it the assurance of the salvation of every Israelite: 'All Israelites have a share in the world to come, as is said: "Then all your people will be righteous ... the branch of my planting"' (m. Sanh. 10.1).

43.In Isaiah 42:6-7, Israel is called to be a light for the Gentiles and to open the eyes of the blind (cf. Wis. 18:4). According to Paul, the Jewish people considered themselves to be a 'guide for the blind, a light for those who are in the dark' ( $\mathrm{Rm}$ 2:19).

44.On the surface level it seems as if the $\pi \alpha \rho \alpha \beta 0 \lambda \eta$ would refer to the parables in verses 13-14 of the planting of blind guides. However, the word should rather be interpreted as an analogy with a broader reference referring to all the material in verses 11-14. 


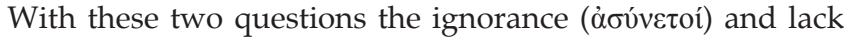

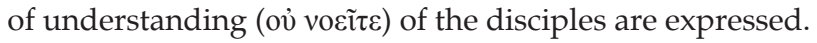

In the first question (v. 16), Jesus expresses his disappointment that the disciples, after all he taught and

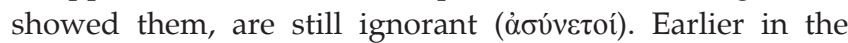
text Jesus implies that his disciples are 'teachers of the law' (Mt 13:52), but now they fail to comprehend his charge that the Pharisees teach the law incorrectly. This remark made by Matthew's Jesus, is probably intended as a warning to the Matthean community about their lack of discernment about the role of the Pharisees and their traditions in their community.

In the second question Jesus elaborates on the statement he made to the crowds. Jesus' response is once again given in parallel form with contrasting phrases:

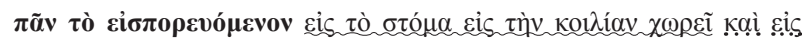

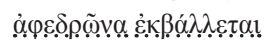
[Whatever enters the mouth goes into the stomach and then out of the body] (v. 17).

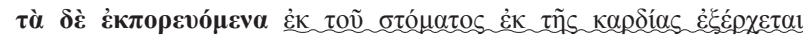

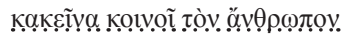
[But the things that come out of a person's mouth come from the heart, and these defile them] (v. 18).

The first part of the parallelism explains what does not defile a person (referring to the first half of verse 11), whilst the second explains what does (referring to the second half of v. 11). The contrast lies between what goes into the mouth (Eic), and what comes out of it (i்k). Things entering the mouth do not defile a person. What enters the stomach is expelled again. It does not enter the heart (only the stomach) and therefore cannot defile a person (Luz 2001:333). However, the inner thoughts of the heart define a person's integrity. Similar sentiments are found in Philo's writings, which state that impurity is primarily injustice and godlessness (Spec. leg. 3.208-9). The true character of a hypocrite (v. 7) is a person who pretends to be religious by performing outward ceremonies, but whose inner person is defiled. This explanation by Jesus must be interpreted according to biological and anthropological views of the 1st century Mediterranean people (Malina \& Rohrbauch 1992:56, 110). They considered that stuff one puts in one's mouth, will eventually be expelled. However one's heart and mouth, when speaking, represent two zones of interaction with the outside world. The speaking mouth forms part of selfexpression and is self-revealing. The heart forms the centre of the emotion-fused zone that involves understanding, choosing, loving, thinking and valuing. Jesus argues that what one speaks, reveals the centre of one's emotion-fused zone.

In contrast to external food (food that may be contaminated with unwashed hands), which does not defile a person, Jesus continues to talk about things that come out of the mouth, which indeed defile a person or exhibit the inner defilement of a person.
The evils in the heart are then listed. ${ }^{45}$ Lists of vices and virtues are common in Hellenistic Judaism (e.g. Wisdom of Solomon, 14:25-26; Philo, Sacr. 32; 4 Macc. 1:26-27; 1QS 4.8-11) and in the New Testament (e.g. in Rm 1:29-31; 1 Cor 6:9-10; 2 Cor 12:20; Charles 2000:1252-1257). Matthew starts with evil thoughts, which can lead to all kinds of evil

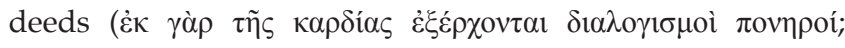
[for from the heart comes all evil thoughts]). What is pure or impure extends from what the person says or does. ${ }^{46}$ Matthew's Jesus thus links cleanness with integrity. Integrity is revealed in a person's deeds. Jesus describes these deeds based on the second table of the Decalogue (as the lists in 1 Cor 5:9-10; $1 \mathrm{Tm}$ 9-10). These commandments follow immediately after the 5th commandment, which was under discussion when Jesus responded to the Pharisees and scribes (v. 4): murders $^{47}$ (6th), adulteries and fornications (7th), thefts (8th), false testimonies and blasphemies ${ }^{48}$ (9th). Jesus points out that impurity does not come from overlooking some ceremonial physical regulation, but from one's innermost being (Loader 1997:220; Morris 1992:389). Personal sin, and not eating with unwashed hands, is what defiles a person. This signifies a shift from cultic purity (hand-washing ceremonies and the corban) towards moral purity. ${ }^{49}$

In his conclusion, Jesus refers back to the issue of eating with unwashed hands stated in verse 2 and gives the final verdict. He specifically applies the principle stated in verse 11 to the issue of hand-washing. The ritual of hand-washing does not ensure true purity. Jesus challenges the traditions of the Pharisees and focuses on a person's attitude. Jesus' teaching discards the idea that human beings are pure in themselves, and that they only have to keep away from the impurities from outside to remain pure. Evil is in the innermost part of a human from where it proceeds to the outside.

What therefore matters above all is the purity of one's heart. Purity of heart was a fundamental teaching of the prophets (e.g. Is 1:12-17; Senior 1998:178). This correlates to the moral instruction of Matthew 5:8 ('Blessed are the pure in heart').

\section{Conclusion}

The story of v. 1-20 provides yet another scene in the overall picture of Matthew's Jesus and the Torah. It provides an explanation of the relationship between Matthew's Jesus and the tradition of the Pharisees and the Law of Moses. The

45.Didache 5.1 contains a part of Matthew's vice list and hence is probably dependent on Matthew.

46.This remark probably harks back to Mt 12:34: 'You brood of vipers! How can you speak good things, when you are evil? For out of the abundance of the heart the mouth speaks' (Evans 2012:302). What comes out of one's mouth is what defiles a person.

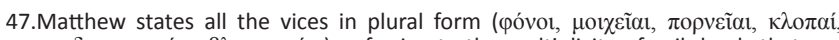

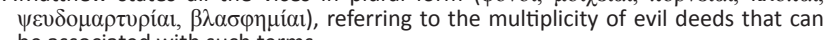
be associated with such terms.

48.It is significant that Matthew adds blasphemy ( $\left.\beta \lambda \alpha \sigma \varphi \eta \mu i_{1} \alpha\right)$, which is not found in Mark's list. Its inclusion was most probably prompted by the experience of slander Jewish communities.

49.This shift is also recognisable in Matthew's reference to Hosea 6:6, 'I desire mercy, not sacrifice' in his Gospel. This reference does not occur in one of the other Gospels. Matthew does this twice: when the Pharisees object that Jesus eats with tax collectors and sinners (Mt 9:13), and when the Pharisees object that his disciples pick some heads of grain to eat on the Sabbath (12:2). 
basic matter in this scene is that Jesus contrasts the tradition of the Pharisees with the written Torah. Whilst Matthew's Jesus makes no explicit remark on food laws (as in Mark's version), he rejects the tradition of the Pharisees on the handwashing ritual. He does not oppose the Mosaic Law, but the Pharisaic oral tradition.

In this story, two issues regarding the observance of the Law are accentuated. Firstly, the Law given by God is contrasted with the regulations made by the Pharisees. Several words and phrases are used to refer to the Law as given by God: the

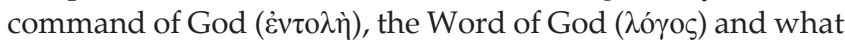

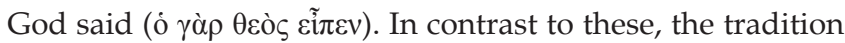
( $\pi \alpha \rho \alpha \dot{\delta} \delta \sigma \iota \varsigma)$ of the Pharisees is mentioned as regulations made by humans. They are teaching teachings of human

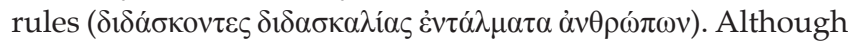
the tradition was intended to prevent that infringement of the Law of God takes place, Jesus accuses the Pharisees of letting the opposite happen. Jesus puts it very strong: Not despite of adding their tradition to the Torah, but because of

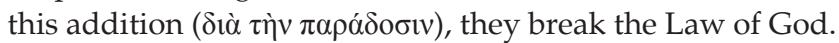

The second issue relates to the locus and origin of impurity and this is illustrated with reference to the tradition of handwashing. The idea behind the hand-washing ritual is that the locus of impurity lies outside a person. Accordingly, impurity can enter a person from outside through the mouth. A person should avoid taking in impurities by observing cultic practices such as hand-washing before eating. Jesus discards this kind of thinking. The locus of impurity lies in the heart - the innermost part of a person. One's heart is considered as the affective centre or desire producer of one's being. From an evil heart, all kinds of evil deeds emerge, but Jesus urges his disciples to seek a pure heart. Earlier in the Gospel Jesus told his disciples: 'Blessed are the pure in heart, for they will see God' (Mt 5:8). Jesus replaces the Pharisean emphasis on cultic purity with moral purity. Followers of Jesus should be concerned about keeping their hearts clean and not about the threat of impurity from the outside world. From an impure heart all kinds of evil deeds emerge. Human beings are not controlled by external codes of conduct, but by that which emerges from their inner hearts.

Matthew tells this story to inform his audience of this dispute between Jesus, the Pharisees and the scribes (on the first level of the story), but also to form their identity (on the second level). Several devices can be recognised, which Matthew employs to define his community and distinguish them from outsiders.

The Matthean community should identify themselves with the disciples in the story. Commitment to Jesus and his teachings form the central focus of their identity. Jesus, as the Son of God, should be revered as having the authority to interpret the Law and to critique the Pharisees. As his disciples, the community is not supposed to be ignorant or lack understanding of Jesus' teaching. Jesus' performative teaching is intended to convince his disciples and, per implication, the Matthean community.
They should comprehend the teachings of Jesus as the ultimate interpretation of the Torah and adhere to it. They should reject the oral tradition of the Pharisees and their traditional interpretation of the Torah, as it poses a threat to the observance of the written Law of God. This story implies an estrangement of the Matthean community from Judaism of the 'Dual Torah' that considered the memorised tradition equally as important as the written Torah. The community should expect to be confronted because of their loyalty towards Jesus and their negation of the oral tradition. Whilst the oral tradition attends to external purity, the moral behaviour of Matthew's community should be governed by inner purity. The community should realise that religious activities, performed without heartfelt commitment towards God, are worthless.

In the story the two outsider groups are the Pharisees (with the scribes) and the crowds.

The Pharisees (with the scribes) are portrayed as the opponents of Jesus. This outsider group somehow reflects the people who challenge the Matthean community because of their loyalty towards Jesus. These outsiders interpret the Torah according to the tradition of the Pharisees. They could also be identified with those who confront the community for their rejection of the duality of the Torah. These outsiders are labelled as people unable to understand the teachings of Jesus. They strictly perform formal religious rituals, but without heartfelt commitment to God. They are also labelled as hypocrites who pretend to honour God, but who ultimately fail in doing so. They perform cultic ceremonies, but neglect moral duties. They are depicted as blind guides who mislead others with their teachings. Although they attempt to improve their observance of the Law by ways of the tradition, they actually nullify the Word of God in this way. For this delusion they will be judged on judgement day.

The other outsider group is the crowds. The crowds probably reflect Jewish people or gentiles who stand neutral and who do not yet have convictions about Jesus. For Matthew the mission to Israel and the gentiles has to continue. They are potential believers. Jesus and his teachings can be proclaimed to them. If they listen, they can be brought to understanding. Whilst the Matthean community proclaimed Jesus to neutral outsiders, they are reminded that these people should have the opportunity to listen and be brought to the understanding of Jesus' teachings rather than that of the Judaism of the dual Torah as presented by the Pharisees.

From this story it seems that both the Matthean community as the Pharisean movement with whom they interacted in their time were much concerned about the correct interpretation of the Torah. It seems that the Pharisaic movement held some attraction for and influence on members of the society. This story warns the society against the Pharisaic movement. They are labeled as hypocrites and blind guides that would lead the blind into a pit. The story proposes the teaching of Jesus to be the true interpretation of the Torah. People with 
insight and understanding should realise this. It seems as if the objection of the opponents was directed against customary practices of the Matthean community. Matthew counters their objection by arguing that his community is more faithful to the commandments of God. He argues that the traditions of the Pharisees and the scribes are opposed to the Word of God. He claims that the greater faithfulness of his community is based on the authority of Jesus. He describes Jesus as the superior interpreter of the Torah.

\section{Acknowledgements \\ Competing interests}

The author declares that he has no financial or personal relationship(s) that may have inappropriately influenced him in writing this article.

\section{References}

Austin, J.L., [1962] 2005, How to do things with words, University Press, Cambridge.

Bailey, J., 2000, 'Vowing away the fifth commandment: Matthew 15:3-6/Mark 7:9-13', Restoration Quarterly 42,193-209.

Baumgarten, A.I., 1987, 'The Pharisaic Paradosis', Harvard Theological Review 80(1), 63-77.

Behm, J., 1978, 'Heart', in G. Kittel (ed.), Theological Dictionary of the New Testament vol. 3, pp. 608-617, William Eerdmans Publishing Company, Grand Rapids.

Blass, F. \& Debrunner, A., 1961, A Greek grammar of the New Testament and other early Christian literature, Chicago University Press, Chicago.

Booth, R.P., 1986, 'Jesus and the laws of purity: Tradition History and Legal History in Mark 7', Journal for the study of the New Testament, suppl. ser. 13.

Bowley, J.E., 2000, 'Purification texts', in C.A. Evans \& S.E. Porter (eds.), Dictionary of New Testament Background, pp. 873-874, InterVarsity Press, Downers Grove \& Leicester.

Carlston, C.E., 1968-69, 'The things that defile (Mark vii. 14) and the Law in Matthew and Mark', New Testament Studies 15, 75-96. http://dx.doi.org/10.1017/ S0028688500018956

Carter, W., 2000, Matthew and the margins: A Socio-Political and Religious reading, Sheffield: Academic Press, Sheffield. (Journal for the Study of the New Testament Supplement series, 204).

Charles, J.D., 2000, 'Vice and virtue lists', in C.A. Evans \& S.E. Porter (eds.), Dictionary of New Testament Background, pp. 1252-1257. InterVarsity Press, Downers Grove \& Leicester.

Cohen, S.J.D., 2006, From the Maccabees to the Mishnah. Westminster John Knox Press, Louisville \& London.

Davies, W.D. \& Allison D.C., 2004, A Critical and exegetical commentary on the Gospe according to Saint Matthew (Matthew 8-18), vol. 2, T\&T Clark International, London \& New York. (International Critical Commentary).

Derret, J.D.M., 1977, Studies in the New Testament, Brill, Leiden.

Dunn, J.D.G., 2003, Jesus remembered: Christianity in the making, vol. 1, Eerdmans, Grand Rapids \& Cambridge.

Elliot, J.K., 1977, 'Jerusalem in Acts and the Gospels', New Testament Studies 23 462-469. http://dx.doi.org/10.1017/S002868850001242X

Evans, C.A., 2012, Matthew, Cambridge University Press, Cambridge. (New Cambridge Bible Commentary).

Finklestein, I., 1966, The Pharisees, Jewish Publication Society, Philadelphia.

France, R.T., 2007, The Gospel of Matthew, Eerdmans, Grand Rapids. (The New International Commentary of the New Testament).
Gundry, R.H., 1994, Matthew: A commentary on his handbook for a mixed church under persecution, Eerdmans, Grand Rapids.

Hagner, D.A., 1995, Matthew 14-28, Word Books, Dallas. (Word Biblical Commentary, 33B).

Hauck, F., 1964, 'Ni $\pi \tau \omega$, övi $\pi \tau \varsigma^{\prime}$ ', in G. Kittel (ed.), Theological Dictionary of the New Testament, vol. 4. pp. 946-948, Eerdmans, Michigan.

Herr, M.D., 2007, 'Yadayim', in F. Skolnik \& M. Berenbaum (eds.), Encyclopaedia Judaica, 2nd ed, vol. 21, p. 264, Thompson Gale, Detroit, New York, San Francisco, New Haven, Waterville, Maine \& London.

Klijn, F.J. \& Reinink, G.J., 1973, Patristic evidence for Jewish-Christian sects, Brill, Leiden. http://dx.doi.org/10.1163/9789004268401

Loader, W.R.G., 1997, Jesus' attitude towards the Law, Mohr Siebeck, Tübingen. (WUNT 2, 97).

Luz, U., 2001, Matthew 8-20, Fortress Press, Minneapolis.

Malina, B.J. \& Rohrbauch, R.L., 1992, Social-science commentary on the Synoptic Gospels, Fortress Press, Minneapolis.

Morris, L., 1992, The Gospel according to Matthew, William Eerdmans, Grand Rapids \& Leicester.

Neusner, J., 1971, The Rabbinic traditions about the Pharisees before 70, Brill, Leiden.

Neusner, J., 1973, From Politics to Piety: The emergence of Pharisaic Judaism, Prentice Hall, Englewood Cliffs.

Neusner, J., 1977, 'Judaism after the destruction of the temple', in J.H. Hayes \& J.M. Miller (eds.), Israelite and Judaean History, p. 670, SCM Press, London.

Neusner, J., 1994, Introduction to rabbinic literature, Doubleday, New York, London, Toronto, Sydney \& Auckland.

Neusner, J., 2007, Judaism, Routledge, London \& New York.

Newton, M., 1985, The concept of purity at Qumran and in the Letters of Paul, Cambridge University Press, Cambridge. http://dx.doi.org/10.1017/CBO9780511555022

Osborne, G.R., 2010, Matthew, Zondervan, Grand Rapids. (Zondervan exegetical commentary on the New Testament).

Overman, J.A., 1990, Matthew's Gospel and formative Judaism: The social world of the Matthean community, Fortress Press, Minneapolis.

Repschinskl, B., 2000, The controversy stories in the Gospel of Matthew: Their redaction, form and relevance for the relationship between the Matthean community and formative Judaism, Vandenhoeck \& Ruprecht, Göttingen.

Schiffman, L., 1994, Reclaiming the Dead Sea Scrolls, Jewish Publication Society of America, Philadelphia.

Senior, D., 1998, Matthew, Abingdon Press, Nashville. (Abingdon New Testament Commentaries).

Stanton, G., 2013, Studies in Matthew and early Christianity, Mohr Siebeck, Tübingen. (WUNT 309).

Talbert, C.H., 2010, Matthew, Baker Academic, Grand Rapids. (Paideia commentaries on the New Testament)

Turner, D.L., 2008, Matthew, Baker Academic, Michigan.

Viljoen, F.P., 2009, 'A contextualised reading of Matthew 6:22-23: "Your eye is the lamp of your body"', HTS Theological Studies 65(1), Art. \#152, 5 pages.

Viljoen, F.P., 2011, 'The foundational statement in Matthew 5:15-20 on the continuing validity of the Law', In die Skriflig 45 (2\&3), 385-408.

Viljoen, F.P., 2012, 'Die gesag waarmee Jesus geleer het volgens Matteus 7:29', HTS Theological Studies 68(1)

Viljoen, F.P., 2013a, 'Righteousness and identity formation in the Sermon on the Mount', HTS Theological Studies 69(1).

Viljoen, F.P., 2013b, 'The righteousness of Jesus and John the Baptist as depicted by Matthew', In die Skriflig/In Luce Verbi 47(1).

Viljoen, F.P., 2013c, Jesus' halakhic argumentation on the true intention of the law in Matthew 5:21-48, Verbum et Ecclesia 34(1)

Viljoen, F.P., 2014, 'Hosea 6:6 and identity formation in Matthew', Acta Theologica 34(1), 214-237.

Walker, L.L., 2000, 'Heart', in D.N. Freedman, A.C. Myers \& A.B. Beck (eds.), Eerdmans Dictionary of the Bible, p. 365, William Eerdmans Publishing Company, Grand Rapids \& Cambridge.

Witherington, B., 2006, Matthew, Zmyth \& Helwys, Macon 